\title{
FOLIAR SALT TOLERANCE OF ACER GENOTYPES USING CHLOROPHYLL FLUORESCENCE
}

\section{by Glynn C. Percival'1, Gillian A. Fraser' ${ }^{2}$, and Gavin Oxenham ${ }^{3}$}

\begin{abstract}
The effect of increasing salinity on a range of chlorophyll fluorescence parameters in foliar tissue of 30 Acer genotypes was examined. The magnitude of the fluorescence responses differed among genotypes ranging from minor effects to substantial leaf tissue damage. Interpretation of the fluorescence expressions provided an insight into mechanisms of salt damage and resilience among genotypes. Based on reductions in a performance index (PIp) following salinity, genotypes were ranked in order from tolerant to sensitive. Based on this ranking criterion, marked differences in salt tolerance among genotypes were distinguished. It is concluded that chlorophyll fluorescence offers a rapid screening technique for assessing the foliar salinity tolerance of urban trees.
\end{abstract}

Key Words. Salinity tolerance; urban trees; sodium; chloride; maple; Acer.

Tree deaths due to de-icing salt $(\mathrm{NaCl})$ application are a major problem in urban landscapes in colder climates (Dobson 1991). Symptoms of excess salinity include crown dieback, lesions on the stem or trunk, and leaf scorch. In addition, symptoms may accumulate (e.g., tip burn of conifer), leading to necrosis of needles that can lead to dieback of limbs and tree death. A range of remedial measures exists to combat this problem. These measures include the use of tree guards as physical barriers; leaching the contaminated area with water, urea, glycol, or calcium magnesium acetate as alternatives to $\mathrm{NaCl}$; or displacing sodium ions from cation exchange sites in the soil by applications of gypsum, a calcium-based compound. Perhaps the simplest approach is to be aware of the relative tolerance of species and genera to salinity and to select the appropriate genotype.

The Acer genus consists of 150 species of evergreen and deciduous trees and shrubs from Europe, North Africa, Asia, and North and Central America. Acer species possess the aesthetic characteristics required of urban trees, such as good autumn color and/or attractive bark. Similarly, those few species used in urban planting schemes tend to establish and survive despite the harsh environmental conditions that prevail (excess salinity, root deoxygenation, drought, etc). Based on survival rates post-planting, an appreciation of salinity tolerance of a few Acer genotypes has emerged; however, no scientifically based tolerance ranking exists.
Photosynthesis occupies the central position within plant biosynthesis that provides a link between the internal metabolism of a tree and the external environment. Part of the light energy absorbed by leaf chlorophyll pigments during photosynthesis is emitted as fluorescence. Analysis of the fluorescence characteristics, such as the nature and intensity of the emission bands, quantum yield, and induction kinetics, reflects the properties of the chlorophyll molecules and their environment. Consequently, alterations to these characteristics as a result of environmental stress can be used to study photosynthetic electron transport and associated physiological processes (Hall and Rao 1999). Therefore, chlorophyll fluorescence is routinely used as a rapid, sensitive, and nondestructive test for the assessment of the salinity, drought, heat, pollution, and chilling tolerance of plants. Chlorophyll fluorescence has proved particularly useful in salinity-tolerance screening programs (Jimenez et al. 1997) because the effects of salt damage can be detected prior to visible signs of deterioration (West 1986). Percival and Fraser (2001) used chlorophyll fluorescence as a diagnostic tool to identify salt-tolerant trees. Marked differences in sensitivity among species within the Crataegus genus were recorded. It therefore appears that chlorophyll fluorescence provides a means by which to identify salt-tolerant genotypes for urban landscape plantings. Aims of this study were to identify whether differences in foliar salt tolerance exist within the Acer genus and thereby provide information as to their usefulness for planting in areas where de-icing salts are applied or that are subject to airborne salt, such as coastal regions.

\section{MATERIALS AND METHODS Plant Material}

Leaf material from 30 Acer genotypes (Table 1) was collected from trees planted throughout Auchincruive Arboretum, Ornamental Gardens and Estate located at the Scottish Agricultural College, Ayr; the Edinburgh Botanic Garden, Edinburgh; and Mansion Field Plants, which is a commercial supplier of trees. All institutes are located within Scotland, UK, within an 80-km radius of each other. Reference to Estate and Arboretum records of planting plans indicated all genotypes selected for use in this experiment were derived from UK provenances. On the morning of each sampling date, shoots consisting of current year's growth were collected from 1 to 13 trees depending on genotype (Table 1) and placed in paper bags for transport to the laboratory. 


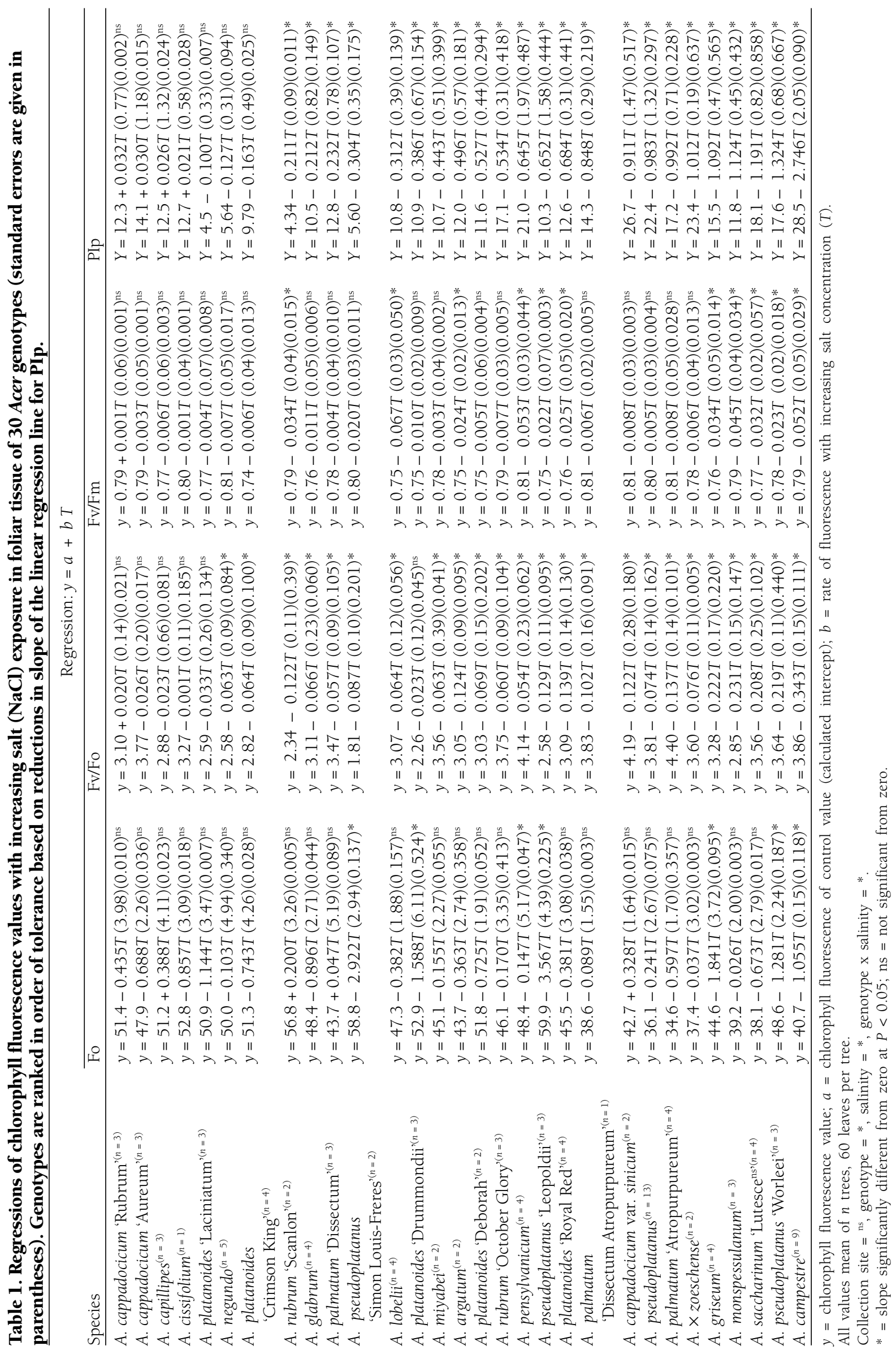


Thirty fully expanded, nonsenescing leaves per tree were excised of the base of the petiole using a razor blade, and all material was prepared within $2 \mathrm{~h}$ of collection. Upon arrival at the laboratory, leaves were immersed in a 0\% (control), $2 \%, 6 \%$, or $9 \%$ salt $(\mathrm{NaCl})$ solution for 2 min. After salt immersion, leaves were placed, abaxial surface down, in a Petri dish on moist Watman filter paper sealed with a thin polythene film permeable to air but not water. Following all treatments, leaf samples were placed in a Merck Environmental Growth Chamber in darkness at $22^{\circ} \mathrm{C}$ for $72 \mathrm{~h}$, a time after which detrimental effects on chlorophyll fluorescence values could be detected (Greaves and Wilson 1987).

\section{Chlorophyll Fluorescence}

After $72 \mathrm{~h}$, light exclusion clips were attached to the leaf surface leaves for $30 \mathrm{~min}$, and chlorophyll fluorescence was measured using a portable fluorescence spectrometer supplied by Hansatech Instruments Ltd., Kings Lynn, UK (Percival et al. 1999). Fluorescence values recorded included:

Fo: Minimal fluorescence. A measure of the stability of the light-harvesting complex.

Fv/Fo: Estimates the maximum primary yield of photochemistry of photosystem II to provide an estimation of leaf photosynthetic capacity.

Fv/Fm: Represents the maximum quantum yield of photosystem II, which in turn is highly correlated with the quantum yield of net photosynthesis (where $\mathrm{Fm}$ is the maximal fluorescence value and $\mathrm{Fv}=\mathrm{Fm}-\mathrm{Fo}$ ).

PIp: A performance index based on an equation that combines the relationship of calculated relative number of reaction centers (RC) per energy absorbed (ABS) and then multiplied by two expressions describing the yields of light trapping and subsequent electron transport [for full details, see Clark et al. (1998) and Percival and Fraser (2001)]:

$$
\mathrm{RC} / \mathrm{ABS} \times \phi \mathrm{po} /(1-\phi \mathrm{po}) \times \Psi_{0} /\left(1-\Psi_{0}\right)
$$

\section{Statistical Analysis}

Effects on chlorophyll fluorescence values with increasing salt concentration were determined by linear regression, $(y=a+b T)$, where $y=$ chlorophyll fluorescence value; $a=$ chlorophyll fluorescence of control value (calculated intercept); $b=$ rate of fluorescence (slope of the linear regression line) with increasing salt concentration ( $T$ ). Plants were ranked in order of salt tolerance based on reductions in $b$ of PIp values (Clark et al. 2000). ANOVA was used to determine whether each slope was significantly different from zero and the significance of site, genotype, and salinity on chlorophyll fluorescence values at the $95 \%$ confidence level $(P<0.05)$. There was a significant effect of genotype
$(P>0.05)$, so treatment effects were analyzed only within each genotype. Experiments were undertaken in August 1999 and repeated in August 2000. The 1999 and 2000 data sets were not different when compared using a t-test; therefore, values presented represent pooled data for both years. All statistical analysis was performed using the Genstat V program (Lawes Agricultural Trust 1990).

\section{RESULTS}

No significant effect of collection site was recorded in this investigation (Table 1); however, a significant genotypic effect $(P>0.05)$ in response to salinity was observed. This observation is reflected by marked differences in the magnitude of the salinity response (the slope value represented by the letter $b$ ) recorded among genotypes (Table 1 ). For example, PIp values ranged from $y=12.3+0.032 T$ for A. cappadocicum 'Rubrum', indicating this genotype as tolerant to foliar-applied salts, to $y=28.5-2.76 \mathrm{~T}$ for $A$. campestre, indicating this genotype as sensitive to foliarapplied salts. Importantly, this finding emphasizes that measurements of PIp values using chlorophyll fluorescence can distinguish marked differences in salt tolerance among genotypes of the same genera. Increasing salinity reduced Fv/Fo (estimated photosynthetic capacity) and Fv/Fm (photochemical efficiency of photosystem II) of all genotypes tested, with the exception of A. cappadocicum 'Rubrum' where an increase in $\mathrm{Fv} / \mathrm{Fo}$ and $\mathrm{Fv} / \mathrm{Fm}$ values was recorded. This latter response is associated with improved photosynthetic efficiency. In most genotypes, Fo decreased with increasing salinity, except A. capillipes, A. rubrum 'Scanlon', A. palmatum 'Dissectum', A. cappadocicum var. sinicum, and A. monspessulanum, where Fo values increased.

Based on the reductions in PIp values with increasing salt stress, plants were ranked in decreasing order of tolerance (Table 1). In support of this ranking criterion, detrimental effects on remaining fluorescence values were also generally lower in plants with increasing sensitivity. Results for A. griseum typify those for sensitive genotypes (PIp, $y=15.5-$ $1.092 \mathrm{~T} ;$ Fo, $y=44.6-1.841 \mathrm{~T} ; \mathrm{Fv} / \mathrm{Fo}, y=3.28-0.222 \mathrm{~T} ; \mathrm{Fv} /$ Fm, $y=0.76-0.034 T$ ); whereas results for $A$. negundo ranked higher were PIp, $y=5.64-0.127 \mathrm{~T}$; Fo, $y=50.0-$ $0.103 \mathrm{~T} ; \mathrm{Fv} / \mathrm{Fo}, y=2.58-0.063 \mathrm{~T}$; and Fv/Fm, $y=0.81-$ 0.007 T. PIp values for A. cappadocicum 'Rubrum', A. cappadocicum 'Aureum, A. capillipes, and A. cissifolium, ranked as the most tolerant genotypes, increased with increasing salt stress. PIp values in all remaining genotypes decreased with increasing salinity.

\section{DISCUSSION}

Leaf chlorophyll fluorescence responses to increasing salinity were, in the majority of genotypes, manifest by reduced Fv/Fo, Fv/Fm, and PIp values. Similar alterations in fluorescence responses occur in crops and woody perennials subjected to freezing, elevated ozone, heat, heavy metals, 
and excess water (Meinander et al. 1996; Lazar et al. 1997; Lu and Zhang 1998; Pospisil et al. 1998). A difference in Fo responses among genotypes provides an insight into effects at the mechanistic level on the leaf photosynthetic apparatus. For example, an increase in Fo in leaf tissue of the Acer genotypes A. capillipes, A. rubrum 'Scanlon', A. palmatum 'Dissectum', A. cappadocicum var. sinicum, and A. monspessulanum is associated with dissociation of the lightharvesting chlorophyll $\mathrm{a} / \mathrm{b}$ complexes from the reaction center complex of photosystem II (Yamane et al. 2000). A decrease in Fo in all remaining genotypes may reflect alterations to the xanthophyll-cycle-dependent, nonradiative energy dissipation process (Hong and Xu 1999). This indicates one of the initial forms of salt damage within the majority of Acer genotypes is impairment of the photo-protective process that facilitates the dissipation of excess energy within the leaf (i.e., the xanthophyll cycle).

In genotypes ranked as the most salt tolerant (i.e., A. cappadocicum 'Rubrum', A. cappadocicum 'Aureum, A. capillipes, and A. cissifolium), regression slopes of PIp values increased in response to salinity. Likewise in A. cappadocicum 'Rubrum', both regression slopes of Fv/Fo (estimated photosynthetic capacity) and Fv/Fm (photochemical efficiency of photosystem II) were also increased following immersion in salt solutions (Table 1). Increases in these fluorescence expressions are associated with increased photosynthetic efficiency. Previous work has shown stress tolerance in some tree species to be associated with increased rates of photosynthesis (Levitt 1980). Similarly, in a study of the genetic variation in photosynthetic traits within populations of Amaranthus hybridus, Arntz et al. (2000) concluded that lower photosynthetic rates reduce fitness (fecundity and survivorship) between wild-type family lines and single gene mutation lines. Results of this investigation indicate short-term increased photosynthetic efficiency associated with tolerance to salt stress present in some Acer genotypes but not others. The effects of salinity on long-term fluorescence responses remain unknown.

With the exception of A. pseudoplatanus and A. campestre, identified as sensitive and moderately sensitive, respectively, to foliar salts (Braun et al. 1978), information on genotype suitability is poorly developed or nonexistent regarding foliar salt tolerance of Acer genotypes. Results of this investigation indicate that A. cappadocicum cultivars, A. capillipes, and A. cissifolium possess good salt tolerance and should be planted in areas subject to salt exposure such as along de-iced roadways and coastal areas, while species such as A. monspessulanum and A. campestre should be avoided. Planting with more appropriate genotypes offers a simple and effective means of reducing plant mortality. Consequently, species planted will remain healthier and live longer, thereby reducing labor and replacement costs.

Results should, however, be interpreted with some degree of caution with regard to providing genotypes with an absolute foliar salt-tolerance ranking. Many Acer genotypes are propagated from seed and subsequent progeny may possess wide genetic variation. Alternately, genotypes such as A. rubrum possess a very broad ecotypic range, offering an abundance of largely untapped genetic resource to select for flood and drought tolerance (Anella and Whitlow 1999). Where Acer genotypes are propagated clonally, however, and therefore possess a very narrow genetic base, chlorophyll fluorescence offers a more positive means to rank genotypic tolerance.

In conclusion, wide genotypic variation in response to salinity indicates that considerable potential exists in the selection of foliar salt tolerance in urban trees. Further investigations to evaluate a wider range of species and genera are in progress.

\section{LITERATURE CITED}

Anella, L.B., and T. Whitlow. 1999. Flood-tolerance ranking of red and freeman maple cultivars. J. Arboric. 25(1):31-37.

Arntz, A.M., E.H. Delucia, and N. Jordan. 2000. From fluorescence to fitness: Variation in photosynthetic rate affects fecundity and survivorship. Ecology 81(9):25672576.

Braun, G., A. Schonborn, and E. Weber. 1978. Investigations on the relative resistance of woody plants against de-icing salts (sodium chloride). Allg. Forst Jagdz. 149:21-35.

Clark, A.J., W. Landolt, J. Bucher, and R.J. Strasser. 1998. The response of Fagus sylvatica to elevated $\mathrm{CO}_{2}$ and ozone probed by the JIP-test based on the chlorophyll fluorescence rise: OJIP, pp 283-286. In De Kok, J.L., and I. Stulen (Eds.). Responses of Plant Metabolism to Air Pollution and Global Change. Brackhuys Publishers, Leiden, The Netherlands.

- 2000. Beech (Fagus sylvatica L.) response to ozone exposure assessed with a chlorophyll a fluorescence performance index. Environ. Pollut. 109:501-507.

Dobson, M.C. 1991. De-Icing Salt Damage to Trees and Shrubs. Forestry Commission Bulletin 101.

Greaves, J.A., and J.M. Wilson. 1987. Chlorophyll fluorescence analysis—An aid to plant breeders. Biologist 34(4):209-214.

Hall, D.O., and K.K. Rao. 1999. Photosynthesis (6th ed.). Cambridge University Press, Cambridge, UK, pp. 174-180.

Hong, S.S., and D.Q. Xu. 1999. Light-induced increase in chlorophyll fluorescence Fo level and the reversible inactivation of PSII reaction centers in soybean leaves. Photo. Res. 61:269-280.

Jimenez, M.S., A.M. Gonzalez-Rodriguez, D. Morales, M.C. Cid, A.R. Socorro, and M. Caballero. 1997. Evaluation of chlorophyll fluorescence as a tool for salt stress detection in roses. Photosynthetica 33(2):291-301. 
Lawes Agricultural Trust. 1990. Genstat 5 Committee of the Statistics Department, AFRC Institute of Arable Crops Research, Rothamsted Experimental Station, Harpenden, Hertfordshire, UK.

Lazar, D., P. llik, and J. Naus. 1997. An appearance of K-peak in fluorescence induction depends on the acclimation of barley leaves to higher temperatures. J. Lumin. 72:595-596.

Levitt, J. 1980. Responses of Plants to Environmental Stress (Vol. I). Academic Press, New York, NY, pp. 202-207.

Lu, C., and J. Zhang. 1998. Effects of water stress on photosynthesis, chlorophyll fluorescence and photoinhibition in wheat plants. Aust. J. Plant Physiol. 25:883-892.

Meinander, O., S. Somersalo, T. Holopainen, and R.J. Strasser. 1996. Scots pine after exposure to elevated ozone and carbon dioxide probed by reflectance spectra and chlorophyll a fluorescence transients. J. Plant. Physiol. 148:229-236.

Percival, G.C., and G.A. Fraser. 2001. Measurement of the salinity and freezing tolerance of Crataegus genotypes using chlorophyll fluorescence. J. Arboric. 27(5):233-245.

Percival, G.C., C. Boyle, and L. Baird. 1999. The influence of calcium supplementation on the freezing tolerance of woody plants. J. Arboric. 25(6):285-291.

Pospisil, P., J. Skotnica, and J. Naus. 1998. Low and high temperature dependence of minimum Fo and maximum Fm chlorophyll fluorescence in vivo. Biochem. Biophys. Acta 1363:95-99.

West, D.W. 1986. Stress physiology in trees-Salinity. Acta Hortic. 175:322-329.

Yamane, Y., T. Shikanai, Y. Kashino, H. Koike, and K. Satoh. 2000. Reduction of $Q_{A}$ in the dark: Another cause of fluorescence Fo increases by high temperatures in higher plants. Photosyn. Res. 63:23-34.

Acknowledgments. The authors are grateful for funding from the International Society of Arboriculture Research Trust and the Stanley Smith (UK) Horticultural Trust.

\author{
${ }^{1 *}$ R.A. Barlett Tree Laboratory, Europe \\ The University of Reading \\ 2 Early Gate \\ Whiteknights \\ Reading, RG6 6AU \\ United Kingdom
}

\author{
${ }^{2}$ Research Student \\ Department of Plant Sciences \\ Whiteknights \\ University of Reading \\ Reading, RG6 6AU \\ United Kingdom \\ ${ }^{3}$ Research Student \\ Department of Plant Sciences \\ SAC Auchincruve \\ Ayr, KA6 5HW \\ Scotland \\ ${ }^{*}$ Corresponding author.
}

Résumé. L'effet de l'accroissement de la salinité sur les paramètres de fluorescence de la chlorophylle dans des tissus foliaires de 30 génotypes d'Acer a été étudié. La magnitude des réponses de fluorescence différait entre les génotypes, et ce avec des variations allant d'effets mineurs à des dommages substantiels du tissu foliaire. Linterprétation des résultats de fluorescence donnait un aperçu des mécanismes de dommages par le sel et de leur résilience entre les différents génotypes. En se basant sur un index de performance des réductions après la période saline, les génotypes ont été classés par ordre de tolérance à la salinité, en allant du plus tolérant au plus sensible. Grâce à ce critère de classification, des différences marquées de tolérance au sel entre les génotypes ont été distinguées. On en conclut que la fluorescence de la chlorophylle offre une technique rapide de distinction pour déterminer le degré de résistance foliaire au sel pour les arbres urbains.

Resumen. Se examinó el efecto del incremento de la salinidad en un rango de parámetros de fluorescencia de clorofila en tejido foliar de 30 genotipos de Acer. La magnitud de respuesta de fluorescencia difirió entre los genotipos de menor efecto a daños sustanciales del tejido foliar. La interpretación de los resultados proporciona información acerca de los mecanismos de daño por sales y resiliencia entre los genotipos. Con base en esto los genotipos fueron clasificados en orden de tolerantes a sensibles a la salinidad. Se concluye que la fluorescencia de clorofila ofrece una técnica rápida para evaluar la tolerancia a la salinidad de los árboles urbanos. 